Electro-therapentics is recognised as a special branch of our art at all our large hospitals and most of the smaller ones and to all those who have carcfully watched its development it comes somewhat as a surprise that any well-informed medical practitioner should for one moment be-little the assistance and help to medicine and surgery which the intelligent medical study of electro-therapeutics has already conferred.

1 am, Sirs, yours faithfully,

Berlfort-square, W.C., August 8th, 1904. CHISHorm WuLLIAMS.

To the Editors of THE LANCET.

SIRs,-It is indeed sad to see how some members of the profession who love to pose as veritable models of light and leading in ethical matters, disregarding the General Medical Council's notice re "covering," still persist in countenancing unqualified practice by sending their patients to laymen for electrical treatment. The reasons suggested by Dr. $\mathrm{F}$. Stanley Smith in 'THE IsNCE' of August 6th, p. 423, are at the best but poor and specious excuses for such irregularities. They are: expense, squeamishness about having their cliagnosis and ideas of treatment overhauled and lastly, the elementary knowledge of anatomy required for the actual application of electricity.

A medical man who would rashly venture, on the score of expense, to send his patient to a "skilled" bone-setter, "who has an elementary knowledge of anatomy," would, I fear, have a hard time of it in struggling to convince operative surgeons of his singular regard for altruistic principles. So likewise ro ophthalmic surgeons consider as something other than "alsurd to contend that there can be anything harmful to a patient in gotting a skilled layman to" examine " him for diagnostic purposes." A correct diagnosis is the only sure basis of rational treatment A patient who can afford to pay a fee of 30 to 100 guineas for a single operation can well spare an additional two or three guineas for an expert's opinion that will clinch the diagnosis in a doubtful case. Again, a skiagram is no more a measure of the exact value of a medical radiographer's services than a bottle of physic is of that of the veneral practitioner who dispenses. It is true that a certain section

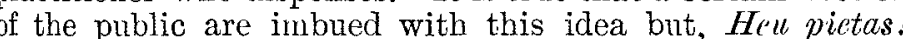
similar views are not held in professional circles. By those best fitted to express an opinion radioscopy rather than radiography is regarded as the surest guide to a correct diagnosis, although the latter has its uses for purposes of localisation and as confirmatory cvidence in a court of law. It may easily be inferred from what has been already said that a skiagram is only a record of one phase of an examination with the Roentgen rays. It requires a vast amount of training to correctly interpret skiagraphic records in a search for calculi, effusions, tumour formations, \&c.; even more experience is needed to tell which surface of the body or part was in immediate relation with the plate. This being the case, surely a labourer is worthy of his hire.

A great and wise physician has said, "We can learn a lot by our very mistakes, and none but a conceited ass would allow vanity to stand in the way of knowledge." 'Thank goodness, the profession at large are not to any extent afllicted with this troublous complaint, which spells death to consultations between medical men, whether specialists or general practitioners. How much reliance can be placed on "the "skilled" layman "nko has an elementary knonledge of anatomy"? Is he likely to prove the superior of the average medical student in this respect? It cannot be too strongly emphasised that something more than a thorough acquaintance with the working of electrical apparatus and an elementary knowledge of anatomy is essential to success in electrotherapy. Experience that combines medical knowledge with that of the physiological and pathological effects of treatment and mastery of electrical instrumentation alone can guide us in making a juclicious selection of cases and in planning out the exact combination that will prove most efficacions. The ordinary knowledge of disease of the practitioner who sends his cases to the skilled layman, who has a sound knowledge only of the workings of his apparatus, cannot supply this deficiency. Experience, which is a staff to the hand of the wise, is a rod for the back of fools. Unfortunately, in this case the punishment is too often administered by proxy, as it is the patient who suffers both in bealth and pocket for the selfish considerations which prompt his medical attendant to suggest this unethical course.

I am, Sirs, yours faithfully,

Levtonstone, Aug. 9th, 1904.

CLARENCE A. WRIGH'T

\section{FREE OPERATIONS.}

To the Editors of THE LANCET.

Srrs,--Your excellent special article on "Medicine and the Law" in THE LANCE' of August 6th, p. 419, reminds us that in the case in question Miss Thorne operated without fee or reward, and has now been recompensed by the anxiety of a trial and the unpleasantness of a verdict against her. Was this patient really a case deserving: of free operation? Would she not have been able to pay a moderate fee either to a London operator or to one of the excellent surgeons in the town from which she came? I am sure most provincial surgeons could give instances of well-to-do patients who have got operations done free in metropolitan hospitals or nursing homes and whose object in leaving their own localities was to escape the payment of surgical fees. Can any argument be advanced to justify this state of things? Probably it is due to the overcrowded state of the special departments of the profession in metropolitan cities and the desire of junior practitioners to gain experience, but that does not make it right. In some cases it is an abuse of hospital funds subscribed to benefit the deserving poor. In all cases it is an abuse of the charity of the medical profession and an injustice to provincial surgeons. Surely every possible care should be taken to separate the undeserving and often ungrateful from the really poor.

I am, Sirs, yours faithfully,

Belfast, August 8th, 1904. JOHN CAMPBELL.

\section{THE INSURANCE OF MEDICAL MEN AGAINST THE DANGERS OF THEIR PROFESSION.}

To the Editors of THE LANCET.

SIRs,-The first part of the letter which appeared in THE LANCET of July 30th, p. 327, signed by Mr. John MacGregor contains a mis-statement of fact that calls for immediate contradiction. The subject of misrepresentation when raised by my counsel was at once objected to by the counsel representing the Scottish Accident Company and the objection was upheld by the arbitrator who said that it was not material to the matter under arbitation, which he further explained was limited to the terms of the policy which constituted the contract between the parties to the suit. I was therefore precluded from calling evidence on this point, although the agent, Mr. Oroucher, was present in court. The bias underlying the entire letter is so selfevident as to relieve me of the necessity of dealing with any other of the points raised.

I am, Sirs, yours faithfully,

Guy's Hospital, S.F., August 5th, 1904. JNo. EYRE.

\section{THE REPUTATION OF SIR EVERARD HOME.}

To the Editors of THE LANCET.

SiRs, - The reputation of Sir Everard Home is severely dealt with in an annotation in THE LANCET of July 23rd, p. 234. Everyone must admit that he put himself hopelessly in the wrong by burning the bulk of the MSS. of John Hunter 30 years after the latter's death. The circumstance that he did this just after publishing a large work of his own and after his co-executor, Dr. Matthew Baillie, had left London gives to the act a worse complexion. But strict justice must be claimed for every offender, and I ask, Is it fair to write, apropos of John Hunter's MSS., that "the windbag Home owed all his knowledge and reputation to them and became F.R.S. and Hunterian lecturer on the strength of them" ? Home was Hunter's brother-in-law, his pupil from 1772, his senior executor, and he wrote an excellent and appreciative life of Hunter the year after his death in 1793 . The best account of Home that I know is that given by Sir Benjamin Brodie in his autobiography, a little work which is a pattern of candour and right feeling. Brodie was a pupil of Home (1803) and later his assistant, continuing for a number of years to work with him in dissections, in comparative anatomy, \&c. He therefore knew him intimately, and yet being himself connected with Matthew Baillie through the Denmans, and constantly working with Clift, Brodie was also in touch with other custodians of John Hunter's fame, 'The dispassionate 